Quick Menu
Editorial Team
Reviewer
Focus and Scope
Author Guideline
Author Fee(s)
About us
Information
For Readers
For Authors
For Librarians
Current Indexing

Current Issue
Home / About

\section{About}

Jurnal Buana Informatika diterbitkan oleh Fakultas Teknologi Industri Universitas Atma Jaya Yogyakarta sebagai media untuk menyalurkan pemahaman tentang aspek-aspek teknologi teknologi informasi berupa hasil penelitian lapangan atau laboratorium maupun studi pustaka. Jurnal ini terbit dua kali dalam setahun yaitu pada bulan April dan Oktober. Redaksi menerima sumbangan naskah dari dosen, peneliti, mahasiswa maupun praktisi membahas bidang penelitian yang berkaitan dengan computational science, graphics and visualization, human-computer interaction, information management, information assurance and security, platform-based development, parallel and distributed computing, and software engineering. Silahkan menyesuaikan naskah dengan checklist ketentuan penulisan dan template naskah yang bisa diunduh dihalaman website ini.

Journal of Buana Informatika is published by Faculty of Industrial Technology University of Atma Jaya Yogyakarta as a medium to channel understanding about technological aspects of information technology in the form of result of field research or laboratory or literature study. This journal is published twice a year in April and October. The editor receives manuscript contributions from lecturers, researchers, students and practitioners discussing the scopes of computational science, graphics and visualization, human-computer interaction, information management information assurance and security platform-based development, parallel and distributed computing, and software engineering. Please kindly follow the checklist of writing guideline and the manuscript template that can be downloaded in this site.

$$
\text { -jbi }
$$

\section{Other}

Journal Sponsorship

Site Map

About this Publishing System
Notifications

View Subscribe

User

Username

Password

$\square$ Remember me

Login

Template

$\checkmark=$
$\square$
$\square=$

Tools

คู่ MENDELEY

turniting

Journal Content

Search

Search Scope

All

Search

Browse

By Issue

By Autho

ByTitle

Other Journals

Font Size

Ai] $A$ \&A

\section{Share}

Y Tweet 


Quick Menu
Editorial Team
Reviewer
Focus and Scope
Author Guideline
Author Fee(s)
About us
Information
For Readers
For Authors
For Librarians
Current Indexing

Current Issue

\begin{tabular}{|l|l|}
\hline ATOM 1.0 \\
\hline
\end{tabular}

RES 2.0

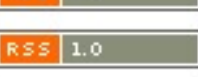

Home / About the Journal

About The Journal

People

: Contact

: Editorial Team

Policies

: Focus and Scope

: Section Policies

" Peer Review Process

: Open Access Policy

\section{Submissions}

: Online Submission

: Copyright Notice

: Privacy Statement

Other

: Journal Sponsorshi

: Site Map

": About this Publishing System

: Statistics

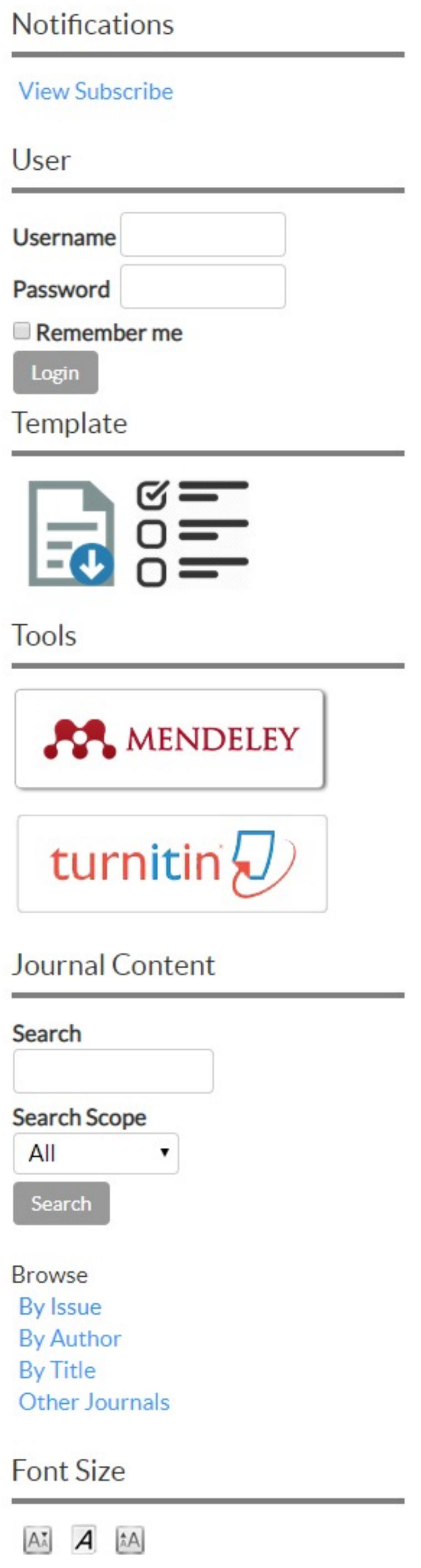

Other

Share

Submissions

Online Submissions

Copyright Notice

Privacy Statement

Section Policies

Peer Review Proces

Open Access Policy

ISSN: 2089-7642 ournal Sponsorship
Jurnal Buana Informatika Site Map

About this Publishing System

Statistics
Y Tweet

Kantor Jurnal Buana Informatika, Teknik Informatika
Teknologi Industri, Universitas Atma Jaya Yogyakarta

Kampus 3, Gedung Bonaventura

Jln. BabarsariNo. 43, Caturtunggal, Kec. Depok, Kabupaten Sleman, DIY 55281

Telp. (0274) 487711 ext. 3153 // Fax. (0274) 485223

Email:jbi@uajy.acid

This work is licensed under a Creative Commons Attribution-ShareAlike 4.0 


\begin{tabular}{l} 
Quick Menu \\
\hline Editorial Team \\
Reviewer \\
Focus and Scope \\
Author Guideline \\
Author Fee(s) \\
About us \\
Information \\
\hline For Readers \\
For Authors \\
For Librarians \\
Current Indexing \\
\hline Surrent Issue
\end{tabular}

\begin{tabular}{|l|l|}
\hline HTOM 1.0 \\
\hline
\end{tabular}

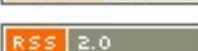

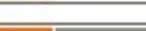

Home / Reviewer

\section{Reviewer}

1. Harry Budi Santoso, S.Kom. M.Kom., Ph.D (Universitas Indonesia) 2. Dr. Yeni Herdiyeni, S.Si, M.Komp. (Institut Pertanian Bogor)

3. Patricia Ardanari, S.Si, M.T. (Universitas Atma Jaya Yogyakarta)

4. Prof. Dr. Ir. Eko Sediyono, M.Kom. (Universitas Kristen Satya Wacana)

5. Dr. Arif Muntasa, S.Si., M.T. (Universitas Trunojoyo)

6. Sudi Mungkasi, Ph.D. (Universitas Sanata Dharma)

7. Wayan Firdaus Mahmudy, Ph.D. (Universitas Brawijaya)

8. Ir Lukito Edi Nugroho. M Sc. Ph D. (Universitas Gadjah Mada)

9. Dr. Onno W. Purbo (Institut Informatika dan Bisnis Darmajaya)

10. Fathul Wahid, Ph.D. (Universitas Islam Indonesia)

11. Ari Sujarwo, MIT (Universitas Islam Indonesia)

12. Dr. Ir. Rudy Hartanto, M.T. (Universitas Gadjah Mada)

13. Dr. Rusdianto Roestam (President University)

14. Rusydi Umar, S.T., M.T, Ph.D. (Universitas Ahmad Dahlan)

15. Riyanto Sigit, ST., M.Kom.,Phd. (Politeknik Elektronika Negeri Surabaya)

16. A. Djoko Budiyanto SHR. Ph. D. (Universitas Atma Jaya Yogyakarta)

17. Dr. Kusrini, M.Kom (STMIK AMIKOM)

8. M. Udin Harun Al Rasyid, S.Kom, Ph.D. (Politeknik Elektronika Negeri Surabaya)

19. Sritrusta Sukaridhoto, ST. PhD. (Politeknik Elektronika Negeri Surabaya)

20. Dr. Veronica Sri Moertini (Universitas Katolik Parahyangan)

21. Tessy Badriyah, S. Kom., M.Kom., Ph.D. (Politeknik Elektronika Negeri Surabaya)

2. Ito Wasito Ph. D. (Universitas Indonesia)

23. Dr. Ridi Ferdiana, S.T., M.T. (Universitas Gadjah Mada)

24. Dr. Awang H. Pratomo (UPN "Veteran" Yogyakarta)

25. Dr. Linggo Sumarno (Universitas Sanata Dharma)

26. Dr. Eng. Chastine Fatichah, S.Kom, M. Kom (Institut Teknik Sepuluh November)

27. Dr. Tatik Maftukhah, MT (Puslit KIM LIPI)

28. Bambang Soelistijanto, Ph. D. (Universitas Sanata Dharma)

29. Wilfridus Bambang Triadi Handaya, S.T., M.Cs. (Universitas Atma Jaya Yogyakarta)

30. Gloria Virginia S.Kom MAI Ph D. (Universitas Kristen Duta Wacana)

31. Dr. Hadi Sutopo, S.Kom. M.M.S.I. (Kalbis Insitute)

32. Yulius Denny Prabowo, S.T., M.T.I. (Kalbis Insitute)

33. Drs. Johanes Eka Priyatma, M.Sc., Ph.D. (Universitas Sanata Dharma)

34. Budi Sutedjo Dharma Oetomo, S.Kom., M.M. (Universitas Kristen Duta Wacana)

35. Prof. Suyoto, M.Sc., Ph.D. (Universitas Atma Jaya Yogyakarta)

36. Dr. Indah Agustien Siradjuddin, S.Kom. M.Kom. (Universitas Trunojoyo$$
\text { Madura) }
$$

77. Pr. Pranowo ST MT (Universitas Atma Jaya Yogyakarta)

38. Fl. Sapty Rahayu S.T., M.Kom. (Universitas Atma Jaya Yogyakarta)

39. Findra Kartikasari Dewi, ST, M.M, M.T. (Universitas Atma Jaya Yogyakarta)
Notifications

View Subscribe

User

Username

Password

$\square$ Remember me

Login

Template

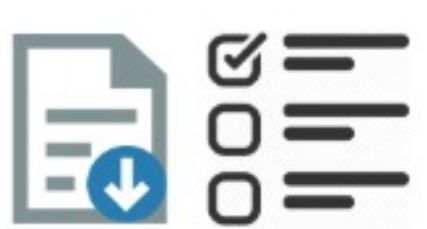

Tools

ชิ่ MENDELEY

turniting)

Journal Content

Search

Search Scope

Al

Search

Browse

By Issue

By Autho

By Title

Other Journals

Font Size

[Ai] $A$ A $A$
Policies

Focus and Scope

Section Policies

Peer Review Proces

Open Access Policy
Submissions

Online Submissions

Copyright Notice

Privacy Statement

\section{Other}

Journal Sponsorship

Site Map

About this Publishing System
Share

Tweet 


\begin{tabular}{l} 
Quick Menu \\
\hline Editorial Team \\
Reviewer \\
Focus and Scope \\
Author Guideline \\
Author Fee(s) \\
About us \\
Information \\
For Readers \\
For Authors \\
For Librarians \\
Current Indexing
\end{tabular}

Current Issue

\begin{tabular}{|l|l|}
\hline ATOM 1.0 \\
\hline
\end{tabular}

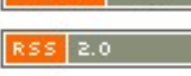

RSSI|.0
Home / About the Journal / Editorial Team

Editorial Team

Editor in Chie

=: Dr. Ir. Albertus Joko Santoso, MT., Universitas Atma Jaya Yogyakarta, Indonesia

\section{Editorial Board Members}

: B. Yudi Dwiandiyanta, Universitas Atma Jaya Yogyakarta, Indonesia :" Inggriani Liem, Institut Teknologi Bandung, Indonesia

: Benyamin L Sinaga, Universitas Atma Jaya Yogyakarta, Indonesia ": Thomas Suselo, Universitas Atma Jaya Yogyakarta, Indonesia

": Dr. Andi Wahju Rahardjo Emanuel, Universitas Atma Jaya Yogyakarta, Indonesia

"Y. Sigit Purnomo WP. Universitas Atma Jaya Yogyakarta, Indonesia

: Paulus Mudjihartono, Universitas Atma Jaya Yogyakarta, Indonesia

": Martinus Maslim, Universitas Atma Jaya Yogyakarta, Indonesia

\# stephanie pamela, Universitas Atma Jaya Yogyakarta, Indonesia

\section{Notifications}

View Subscribe

User

Username

Password

$\square$ Remember me

Login

Template

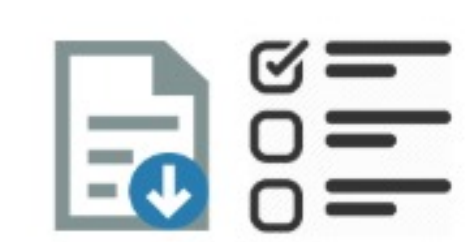

Tools

\begin{tabular}{l} 
Surnitin MENDELEY \\
Journal Content \\
Search \\
Search Scope \\
All \\
Search \\
Browse \\
By Issue \\
By Author \\
By Title \\
Other Journals \\
Font Size \\
\hline Ais $\boldsymbol{A}$ [A
\end{tabular}

\section{Policies}

Focus and Scope

Section Policies

Peer Review Process

Open Access Policy

ISSN: 2089-7642
Jurnal Buana Informatika

Submissions

Online Submissions

Copyright Notice

Privacy Statement

Journal Sponsorship

Share

Tweet

About this Publishing System

Kantor Jurnal Buana Informatika, Teknik Informatika
Teknologi Industri, Universitas Atma Jaya Yogyakarta

Fakultas Teknologi Industri, Universitas Atma Jaya Yogyakarta
Kampus 3, Gedung Bonaventura

Jln. Babarsari No. 43, Caturtunggal, Kec. Depok, Kabupaten Sleman, DIY 55281

Telp. (0274) 487711 ext. $3153 / / F a x$ (0274) 485223

Email:jbi@uajy.ac.id

This work is licensed under a Creative Commons Attribution-ShareAlike 4.0 


Quick Menu
Editorial Team
Reviewer
Focus and Scope
Author Guideline
Author Fee(s)
About us
Information
For Readers
For Authors
For Librarians
Current Indexing

Current Issue

\begin{tabular}{|l|l|}
\hline Arom 1.0 \\
\hline
\end{tabular}

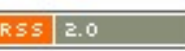
\begin{tabular}{|l|l|l|l|l|l|}
\hline ESS \\
\hline
\end{tabular}
Home / About the Journal / Journal Contact

Journal Contact

Mailing Address

Prodi Teknik Informatika, Fakultas Teknologi Industri Universitas Atma Jaya Yogyakarta

In. Babarsari No. 43. Yogyakarta 55281

Telp. (0274) 487711 Fax. (0274) 485223

E-mail :jbi@uajy.ac.id

\section{Principal Contact}

\section{Vinindita Citrayasa}

Koordinator JBI

Universitas Atma Jaya Yogyakarta

Kantor Jurnal Buana Informatika, Teknik Informatika, Fakultas Teknologi Industri, Universitas Atma Jaya Yogyakarta

Kampus 3, Gedung Bonaventura, Jalan Babarsari No.43, Caturtunggal, Kec. Depok, Kabupaten Sleman, Daerah Istimewa Yogyakarta 55281

Email: jbi@uajy.ac.id

Telepon 027448711 ext. 3153

Hp: 083869607539

Phone: 0274487711

Fax: 0274485223

Email:vinindita_citrayasa@staff.uaiy.ac.id

Support Contact

Andreas Hemawan Tri N

Phone: (0274) 487711 ext. 3041

Email: andreas_hemawan@staff.uajy.ac.id

\section{Notifications}

View Subscribe

User

Username

Password

$\square$ Remember me

Login

Template

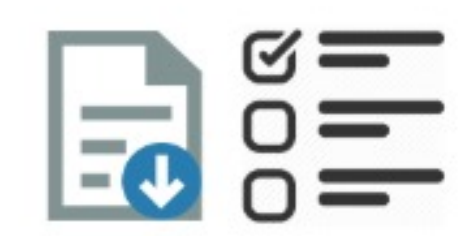

Tools

\begin{tabular}{l} 
Surnitin MENDELEY \\
Journal Content \\
Search \\
Search Scope \\
All \\
Search \\
Browse \\
By Issue \\
By Author \\
By Title \\
Other Journals \\
Font Size \\
\hline Ais $\boldsymbol{A}$ [A
\end{tabular}

\section{Policies}

Focus and Scope

Section Policies

Peer Review Proces

Open Access Policy

ISSN: 2089-7642
Submissions

Online Submissions

Copyright Notice

Privacy Statement

\section{Other}

Journal Sponsorship

Site Map

About this Publishing System

\section{Share}

Y Tweet

Kampus 3, Gedung Bonaventura Jln. Babarsari No. 43, Caturtunggal Kec Depok, Kabupaten Sleman, DIY 55281 


\begin{tabular}{l} 
Quick Menu \\
\hline Editorial Team \\
Reviewer \\
Focus and Scope \\
Author Guideline \\
Author Fee(s) \\
About us \\
Information \\
\hline For Readers \\
For Authors \\
For Librarians \\
Current Indexing \\
\hline Lcholar
\end{tabular}

Current Issue

\begin{tabular}{|l|l|}
\hline ATOM 1.0 \\
\hline RSS 2.0 \\
\hline 5.25
\end{tabular}

Home / Vol 8, No 4 (2017) / Adithama

Rancang Bangun Sistem Informasi Manajemen dan Reservasi untuk Rumah Pembinaan

Stephanie Pamela Adithama, Martinus Maslim, Yulius Harjoseputro, Hisyam Rahmawan Suharno

Abstract

Abstract. Rumah Pembinaan Carolus Borromeus (RPCB) Syantikara is a retreat house that serves the development of ay spirituality through retreat services for youth and adult groups. The reservation record until now is still done manually, raises problems such as: double booked, rooms and facilities do not fit the initial order, the reservation process took a long time. Management information systems and reservation is built to respond the needs of RPCB Syantikara in providing services and assisting managerial decision making. This system can handle management of reservation data recording reservations, transactions and reporting that can bemonitored inreal time. Theresults of system testing to the user indicate that all functionality has been running properly. This system can improve RPCB Syantikara performance, streamline the reservation process, reduce transaction processing time, and improve service quality.

Keywords: retreat house, reservation, information system, information system management

Abstrak. Rancang Bangun Sistem Informasi Manajemen dan Reservasi untuk Rumah Pembinaan. Rumah Pembinaan Carolus Borromeus (RPCB) Syantikara melayani pengembangan spiritualitas awam, melalui pelayanan retret bagi kelompok remaja maupun kelompok dewasa. Pencatatan reservasi hingga kini masih dilakukan secara manual sehingga menimbulkan permasalahan, seperti: double booked, ruangan dan fasilitas tidak sesuai pesanan awal, lamanya waktu untuk memproses reservasi. Sistem informasi manajemen dan reservasi dibangun untuk menanggapi kebutuhan RPCB Syantikara dalam memberikan layanan dan membantu pengambilan keputusan manajerial. Sistem ini dapat menangani proses pengelolaan data-data terkait reservasi, pencatatan reservasi, transaksi, sampai dengan pelaporannya yang dapat dipantau secara real time. Hasil pengujian sistem kepada pengguna menunjukkan bahwa semua fungsionalitas telah berjalan dengan baik. Sistem ini dapat meningkatkan kinerja RPCB Syantikara, mengefisienkan proses reservasi, mengurangi waktu pemrosesan transaksi, dan meningkatkan kualitas pelayanan.

Kata Kunci: rumah pembinaan, reservasi, sistem informasi, sistem informasi manajemen

Notifications

View Subscribe

User

Username

Password

$\square$ Remember me

Login

Template

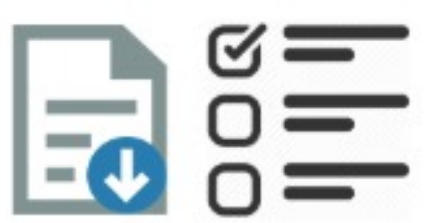

Tools

$\frac{\text { भి MENDELEY }}{\text { turnitin } \square}$

Journal Content

Search

Search Scope

Al

Search

Browse

By Issue

By Author

By Title

Other Journals

Font Size

[A] $A$ [A]

Full Text:

PDF

DOI: https://doi.org/10.24002/jbi.v8i4.1445

Refbacks

": There are currently no refbacks.

Policies

Focus and Scope

Section Policies

Peer Review Process

Open Access Policy
Submissions

Online Submissions

Copyright Notice

Privacy Statement

\section{Other}

Journal Sponsorship

Site Map

About this Publishing System
Share

Tweet 


\title{
Rancang Bangun Sistem Informasi Manajemen dan Reservasi untuk Rumah Pembinaan
}

\author{
Stephanie Pamela Adithama ${ }^{1}$, Martinus Maslim², Yulius Harjoseputro ${ }^{3}$, Hisyam Rahmawan Suharno ${ }^{4}$ \\ Program Studi Teknik Informatika, Fakultas Teknologi Industri,Universitas Atma Jaya Yogyakarta \\ Jl. Babarsari 43, D.I.Yogyakarta 55281, Indonesia \\ Email: ${ }^{1}$ stephanie_pamela@staff.uajy.ac.id, ${ }^{2}$ martinusmaslim@staff.uajy.ac.id, \\ ${ }^{3}$ yulius.harjoseputro@staff.uajy.ac.id. ${ }_{2}^{4} 130707362 @$ students.uajy.ac.id
}

Masuk: 22 Agustus 2017; Direvisi: 14 September 2017; Diterima: 17 September 2017

\begin{abstract}
Rumah Pembinaan Carolus Borromeus (RPCB) Syantikara is a retreat house that serves the development of lay spirituality, through retreat services for youth and adult groups. The reservation record until now is still done manually, raises problems such as: double booked, rooms and facilities do not fit the initial order, the reservation process took a long time. Management information systems and reservation is built to respond the needs of RPCB Syantikara in providing services and assisting managerial decision making. This system can handle management of reservation data, recording reservations, transactions, and reporting that can be monitored in real time. The results of system testing to the user indicate that all functionality has been running properly. This system can improve RPCB Syantikara performance, streamline the reservation process, reduce transaction processing time, and improve service quality.
\end{abstract}

Keywords: retreat house, reservation, information system, information system management

\begin{abstract}
Abstrak. Rancang Bangun Sistem Informasi Manajemen dan Reservasi untuk Rumah Pembinaan. Rumah Pembinaan Carolus Borromeus (RPCB) Syantikara melayani pengembangan spiritualitas awam, melalui pelayanan retret bagi kelompok remaja maupun kelompok dewasa. Pencatatan reservasi hingga kini masih dilakukan secara manual sehingga menimbulkan permasalahan, seperti: double booked, ruangan dan fasilitas tidak sesuai pesanan awal, lamanya waktu untuk memproses reservasi. Sistem informasi manajemen dan reservasi dibangun untuk menanggapi kebutuhan RPCB Syantikara dalam memberikan layanan dan membantu pengambilan keputusan manajerial. Sistem ini dapat menangani proses pengelolaan data-data terkait reservasi, pencatatan reservasi, transaksi, sampai dengan pelaporannya yang dapat dipantau secara real time. Hasil pengujian sistem kepada pengguna menunjukkan bahwa semua fungsionalitas telah berjalan dengan baik. Sistem ini dapat meningkatkan kinerja RPCB Syantikara, mengefisienkan proses reservasi, mengurangi waktu pemrosesan transaksi, dan meningkatkan kualitas pelayanan.
\end{abstract}

Kata Kunci: rumah pembinaan, reservasi, sistem informasi, sistem informasi manajemen

\section{Pendahuluan}

Rumah Retret atau Rumah Pembinaan Carolus Borromeus (RPCB) Syantikara didirikan dengan maksud dan tujuan untuk melayani retret bagi kelompok kaum muda (siswa, mahasiswa), kelompok dewasa (guru-guru, dosen, suster/bruder/imam), lembaga-lembaga pemerintah, lembaga swadaya, lembaga-lembaga gereja, dan masyarakat umum. Selain untuk pelayanan retret, RPCB Syantikara juga menyediakan tempat untuk kegiatan pelatihan/pembinaan, seminar/workshop, rapat, maupun tempat singgah peziarah. RPCB Syantikara memiliki fasilitas ruang pertemuan, aula, kamar-kamar untuk menginap, ruang doa, ruang makan, dan ruang transit. Proses bisnis pada RPCB Syantikara sama dengan proses bisnis pada industri-industri penginapan pada umumnya.

Teknologi Informasi (TI) diterapkan di industri penginapan sebagai aset strategis yang penting. Industri penginapan adalah organisasi yang berorientasi pada pelanggan (Akazue, 
2016). Pelanggan merupakan salah satu aset yang penting dalam pencapaian tujuan organisasi, menjaga hubungan baik dengan pelanggan dengan memberikan pelayanan maksimal mutlak harus dilakukan (Ensour \& Alinizi, 2014). Kepuasan pelanggan dapat dicapai secara maksimal dengan menerapkan TI dalam kegiatan operasional (Falgenti \& Pahlevi, 2013). Informasi memainkan peran penting dalam menjalankan operasi penginapan yang sukses. Penggunaan TI ini dapat memodifikasi pekerjaan dan merestrukturisasi lingkungan kerja, yang berdampak meningkatkan efisiensi proses bisnis, meningkatkan produktivitas, dan mendukung pengambilan keputusan manajemen (Kim, dkk., 2008).

Reservasi adalah bagian penting dari setiap sistem penginapan. Pelanggan di RPCB Syantikara adalah pelanggan kelompok. Pelanggan biasanya akan membuat reservasi beberapa hari atau beberapa minggu sebelum hari kedatangan. Petugas reservasi dan manajemen harus mengambil keputusan untuk hal-hal yang berkaitan dengan proses reservasi, seperti mengalokasikan kamar dan fasilitas bagi pelanggan. Penolakan permintaan reservasi akan dilakukan ketika tidak mampu lagi menyediakan kamar dan fasilitas yang kosong. Setelah pelanggan tiba, bisa terjadi check out sebelum check-out yang diharapkan, yang menyebabkan understay. Selain itu, juga bisa terjadi check-out setelah check-out yang diharapkan, yang menyebabkan melebihi masa tinggal (overstay).

Proses pengolahan data yang dilakukan secara manual, memungkinkan terjadi kesalahan dalam pencatatan, keterlambatan dalam pencarian data, dan kurang akuratnya laporan yang dibuat. Dimulai dari data tamu, data kamar, data reservasi, sampai penyimpanan data-data lainnya yang berhubungan dengan transaksi hingga pembuatan laporan, selama ini masih dilakukan secara manual. Pengolahan data manual memanfaatkan sumber daya yang berbedabeda seperti kertas, papan tulis, atau perangkat lunak seperti Microsoft Word dan Microsoft Excel. Penyimpanan data terpisah-pisah dan tidak terpusat sehingga menyulitkan administrasi dalam memperoleh dan mengelola informasi, terdapat redundansi data dan data yang tidak konsisten. Kelemahan ini juga meningkatkan risiko kehilangan data, baik sengaja atau tidak sengaja (Kurniawan \& Cassandra, 2014).

Untuk menghasilkan informasi yang bermanfaat, data-data yang menjadi sumber informasi perlu dikelola secara baik menjadi satu kesatuan sistem yang disebut Sistem Informasi (SI) (Chandra, 2016). Sistem informasi manajemen (SIM) adalah jenis sistem informasi yang dapat mengumpulkan dan memproses informasi dari berbagai sumber untuk mendukung pengambilan keputusan di tingkat manajemen. SIM mengubah data menjadi informasi dalam bentuk laporan dan menampilkannya untuk mendukung pengambilan keputusan (Al-Mamary, dkk., 2014).

SIM RPCB Syantikara dibangun untuk menanggapi kebutuhan RPCB Syantikara dalam memberikan layanan dan membantu pengambilan keputusan manajerial. SIM RPCB Syantikara ini dapat menangani proses pengelolaan data-data terkait reservasi, pencatatan reservasi, transaksi, sampai dengan pelaporannya yang dapat dipantau secara real time oleh petugas reservasi dan manajemen RPCB Syantikara. Sistem yang dibangun ini dapat menyimpan datadata dan informasi dalam database yang aman dan terpusat. Dengan diterapkannya SIM RPCB Syantikara ini, sumber daya dan informasi diolah secara terintegrasi, sehingga meningkatkan kinerja RPCB Syantikara, mengefisienkan proses reservasi, mengurangi waktu pemrosesan transaksi, meningkatkan kualitas pelayanan, dan meningkatkan kepuasan mitra layanan.

\section{Tinjauan Pustaka}

\subsection{Kajian Literatur}

Penelitian sebelumnya yang berhubungan dengan penelitian ini antara lain sebagai berikut. Osama (2011) mengintegrasikan sistem informasi untuk reservasi kamar pada hotel. Sistem yang dibangun ini menangani reservasi kamar baik individu maupun kelompok, yang juga diintegrasikan dengan sistem akuntansi. Sistem ini juga menangani pembayaran dan pembuatan laporan. Namun, sistem ini dibangun berbasis desktop, sehingga tidak dapat diakses dari mana saja. 
Delizo dan Esguerra (2013), melakukan penelitian untuk membangun sistem reservasi online yang digunakan oleh anggota fakultas dan mahasiswa di College of International Hospitality Management. Dengan sistem ini, mahasiswa mendapatkan pengalaman nyata untuk pekerjaan yang berkaitan dengan reservasi dan manajemen hotel. Sistem ini berfungsi sebagai alat untuk mengajarkan cara reservasi hotel. Hasil penelitian ini masih digunakan secara terbatas untuk keperluan simulasi saja.

Manjunatha, et al (2016), membangun sistem informasi manajemen pada Hotel Sandesh The Prince, yang dapat menampilkan laporan tentang profil pelanggan dan reservasinya. Penelitian ini mempunyai fokus utama pada proses reservasi. Penelitian ini menyimpulkan bahwa penggunaan data secara efektif dapat meningkatkan efisiensi keseluruhan di hotel.

\subsection{Rumah Retret atau Rumah Pembinaan}

Salah satu definisi dari pembinaan adalah suatu proses atau pengembangan yang mencakup urutan-urutan pengertian, diawali dengan mendirikan, menumbuhkan, memelihara pertumbuhan yang disertai usaha usaha perbaikan, menyempurnakan, dan mengembangkan. Pembinaan dalam studi kasus ini yaitu pembinaan iman rohani dan jasmani yang ditujukan kepada masyarakat umum dan umat Kristiani (Alhempi \& Harianto, 2013). Retret berasal dari Bahasa Inggris "retreat" yang berarti mengundurkan diri atau mengasingkan diri. Melalui kegiatan retret, seseorang selain disegarkan jasmaninya, juga rohaninya. Maka dari itu rumah retret atau rumah pembinaan adalah suatu tempat yang menyediakan fasilitas untuk kegiatan retret atau pembinaan iman rohani.

\subsection{Sistem Informasi}

Sistem Informasi adalah suatu sistem di dalam suatu organisasi yang merupakan kombinasi dari orang-orang, fasilitas, teknologi, media, prosedur-prosedur dan pengendalian yang ditujukan untuk mendapatkan jalur komunikasi yang penting, memproses tipe transaksi rutin tertentu, memberi sinyal manajemen terhadap kejadian-kejadian internal dan eksternal yang penting dan menyediakan suatu dasar informasi untuk pengambilan keputusan yang baik (Jogiyanto, 2005). Menurut O'Brien \& Marakas (2011) sistem informasi adalah kombinasi yang terorganisir dari orang, hardware, software, jaringan komunikasi, basis data, dan kebijakan dan prosedur untuk menyimpan, mengambil, mengubah, dan menyebarkan informasi dalam sebuah organisasi. Proses ini didefinisikan sebagai siklus pengolahan informasi yang terdiri dari empat operasi, yaitu input, proses, output, dan penyimpanan (Al-Mamary, dkk., 2014). Sistem informasi dikembangkan dan dibangun karena memiliki manfaat yang besar antara lain: mengurangi biaya, mengurangi kesalahan-kesalahan, meningkatkan kecepatan aktifitas, meningkatkan perencanaan, dan pengendalian manajemen (Aswati, dkk., 2015).

\subsection{Sistem Informasi Manajemen}

Sistem informasi manajemen (SIM) adalah jenis sistem informasi yang dapat mengumpulkan dan memproses informasi dari berbagai sumber untuk mendukung pengambilan keputusan di tingkat manajemen. SIM mengubah data menjadi informasi dalam bentuk laporan dan menampilkannya untuk mendukung pengambilan keputusan (Al-Mamary, dkk., 2014). SIM menghasilkan informasi yang mendukung pengambilan keputusan sehari-hari oleh manajer (Hasan, dkk., 2013). SIM juga meningkatkan performa kerja seluruh institusi. Selain membantu manajemen membuat keputusan strategis, di tingkat lain SIM menyediakan sarana untuk memantau, mengontrol, menjalankan kegiatan organisasi, dan mendistribusikan informasi ke semua bagian organisasi (Munirat, dkk., 2014).

\subsection{Sistem Reservasi}

Pemesanan dalam Bahasa Inggris "reservation" yang berasal dari kata to reserve yaitu menyediakan atau mempersiapkan tempat. Sedangkan reservation yaitu pemesanan suatu tempat beserta fasilitasnya. Reservasi sendiri merupakan suatu permintaan seorang tamu agar memperoleh sejumlah kamar yang diinginkan, yang dilakukan beberapa waktu sebelumnya 
lewat beberapa sumber dan dengan berbagai cara pemesanan dengan tujuan memastikan bahwa tamu tersebut akan mendapatkan kamar pada saat mereka datang (Aprillia, et al., 2017). Sistem reservasi adalah suatu sistem yang menangani mengenai segala sesuatu yang berhubungan dengan pemesanan baik pemesanan kamar, ruang, alat, tiket, dan lain-lain. Sistem reservasi membuat para tamu yang mengunjungi hotel, daerah wisata, dan lainnya bisa memesan tempat tersebut lebih mudah dan efisien menggunakan website (Molchanova, 2014).

\section{Metodologi Penelitian}

Metodologi yang digunakan dalam rancang bangun sistem informasi manajemen dan reservasi untuk rumah pembinaan RPCB Syantikara terdiri dari empat tahap utama yaitu: (1) Analisis. Pada tahap ini dilakukan analisis kebutuhan dan menganalisis data-data yang dibutuhkan. Dilakukan dengan melakukan pengamatan dan wawancara kepada pimpinan dan staf-staf RPCB Syantikara. (2) Perancangan. Pada tahap ini dilakukan perancangan yaitu: perancangan arsitektur, perancangan data, perancangan antarmuka, dan perancangan kelas. (3) Pengkodean. Pengkodean dilakukan untuk mengubah hasil rancangan ke dalam kode program. (4) Pengujian. Pada tahap ini dilakukan proses pengujian fungsionalitas sistem yang telah dibangun.

\section{Hasil Penelitian dan Pembahasan}

\subsection{Analisis}

Permasalahan akibat manajemen reservasi yang kurang baik seringkali menjadi kendala dalam pelayanan. Permasalahan yang muncul dengan sistem manual ini adalah jika ada reservasi yang masuk, petugas reservasi kesulitan melakukan pengecekan kamar dan fasilitas yang kosong. Selain itu, manajemen mengalami kesulitan ketika membutuhkan laporan-laporan yang berkaitan dengan reservasi secara cepat. Permasalahan-permasalahan lain yang juga muncul seperti: sering terjadi double booked, penggunaan ruangan dan fasilitas yang tidak sesuai pesanan awal, jeda antara tamu check-out dan tamu baru yang akan check-in tidak terkontrol sehingga mengakibatkan kurangnya waktu persiapan bagi bagian rumah tangga RPCB untuk melakukan persiapan ruang. Hal ini akan mengurangi kepuasan mitra layanan RPCB Syantikara, bahkan berpotensi komplain mitra layanan. Selain itu ini akan berdampak kerugian finansial bagi RPCB Syantikara.

SIM RPCB Syantikara ini dapat menangani fungsi-fungsi seperti: (1) Proses pengelolaan data reservasi, seperti pengelolaan master data kamar, fasilitas, tarif, pelanggan, pegawai (2) Pencatatan reservasi, seperti pengecekan ketersediaan kamar, ruang pertemuan dan fasilitas penunjang lainnya. Setelah reservasi dicatat, pemesan mendapatkan bukti reservasi/pesanan tempat. Termasuk di dalamnya pembatalan atau perubahan reservasi. (3) Transaksi pembayaran, baik pembayaran down payment maupun pelunasan pembayaran. (4) Pelaporan reservasi yang dapat dipantau secara real time oleh manajemen RPCB Syantikara. Sistem yang dibangun ini berupa website yang bisa diakses darimana saja, sistem dibangun menggunakan PHP dengan framework CodeIgniter. Data-data disimpan dalam database, yaitu menggunakan Database Management System MySQL.

\subsection{Use Case Diagram}

Use case sistem yang dibangun dapat dilihat pada Gambar 1. Terdapat lima aktor yaitu tamu dapat menjalankan fungsi login, mengelola akun pribadi, mengirim pesan, melakukan pemesanan kamar, melakukan pembayaran pemesanan kamar, dan melihat detil pesanan. Administrator dapat menjalankan fungsi login, mengelola akun pribadi, mengelola data master, mengelola data pengguna, mengelola pesan dan notifikasi yang masuk, dan mengelola data konten website. Front office dapat menjalankan fungsi login, mengelola transaksi pemesanan kamar, mengelola dan melihat denah ruangan, mengelola kehadiran tamu, dan mengelola pembayaran transaksi pemesanan kamar. Kepala yayasan dapat menjalankan fungsi mengelola laporan. Sedangkan Sistem dapat menjalankan fungsi memberikan rekomendasi kamar kosong, memberikan notifikasi ke panel admin, dan mengirimkan notifikasi email kepada tamu. 


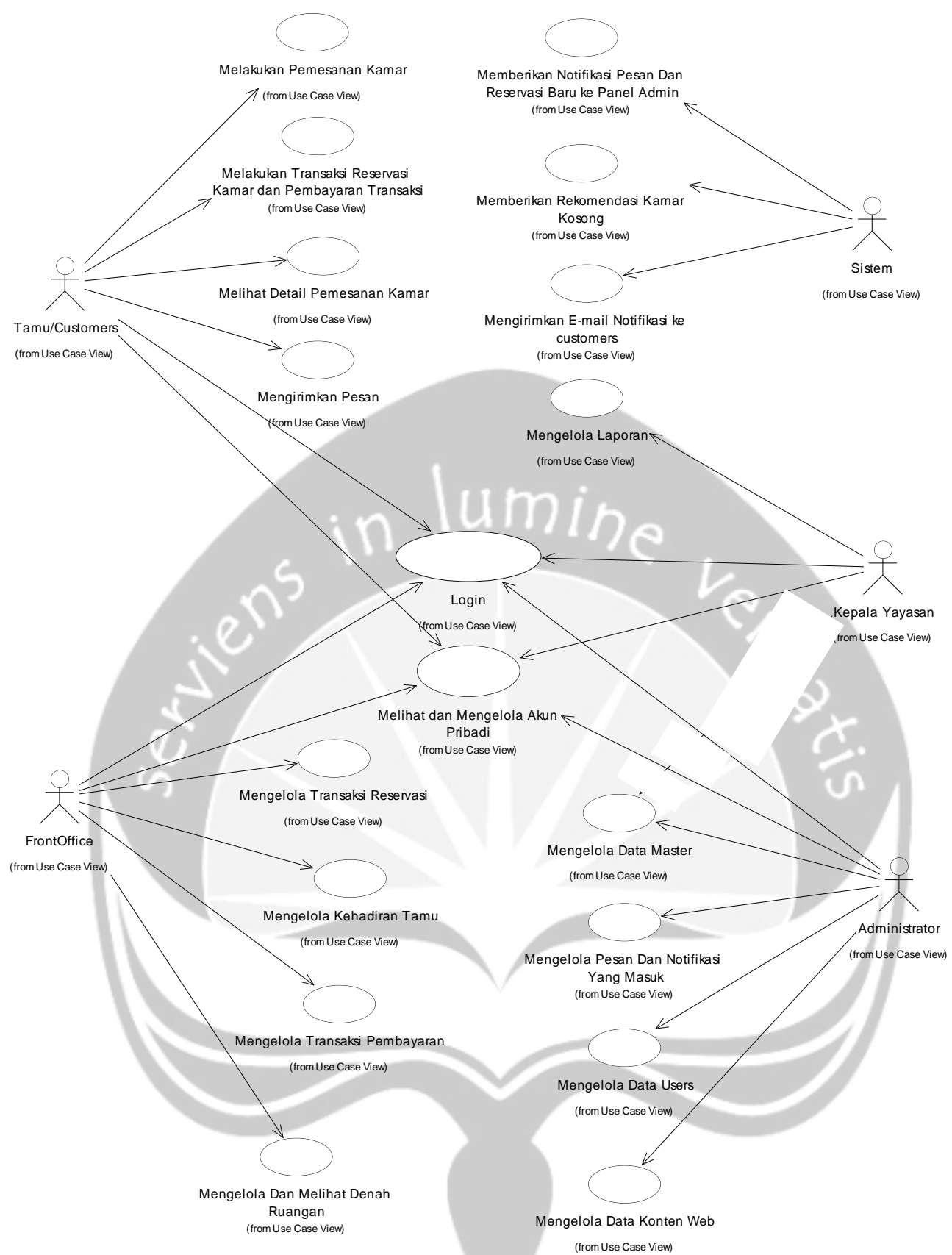

Gambar 1. Use Case Diagram Sistem Informasi Manajemen dan Reservasi

\subsection{Rancangan Basis Data}

Gambar 2 merupakan rancangan basis data, basis data terdiri dari 17 tabel. Tabel-tabel tersebut antara lain tabel users, news, news_category, facilities, gallery, setting, notification, jenis_tamu, jenis_tarif, tarif, ruang, kamar, pertemuan, jasa, master_city, master_provinsi, news_bridge, pesan, setting, user_token, transaksi_detail_additional, additional, transaksi, transaksi_detail. 


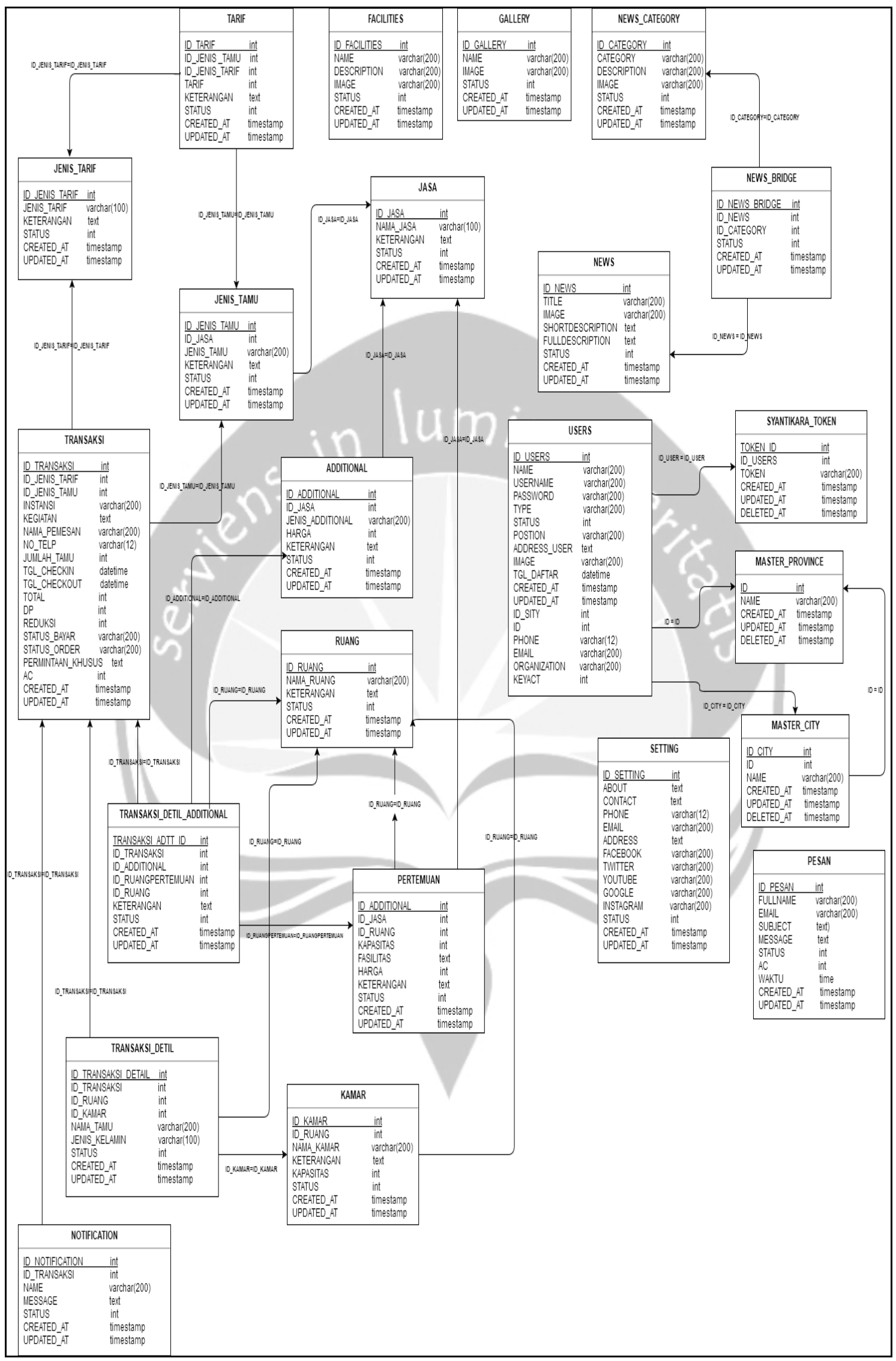

Gambar 2. Rancangan Basis Data 


\subsection{Implementasi Sistem}

Antarmuka pada Gambar 3 adalah antarmuka yang digunakan oleh administrator dan kepala yayasan untuk melihat laporan transaksi reservasi di RPCB Syantikara setiap tahun selama 12 bulan. Laporan tampil berdasarkan tahun yang dipilih pengguna. Akan muncul namanama bulan di tahun tersebut dan data transaksi reservasi yang terjadi pada tahun tersebut di bulan tertentu. Antarmuka pada Gambar 4 digunakan oleh administrator dan front office untuk mengelola pembayaran transaksi reservasi. Setelah melakukan proses pembayaran, sistem akan mencetak nota transaksi, yang dapat dilihat pada Gambar 5.

APRIL
\begin{tabular}{|c|c|c|c|c|c|}
\hline No & Instansi & Contact Person & Tanggal Pemakaian & Kegiatan & Jumlah Peserta \\
\hline
\end{tabular}

MEI

\begin{tabular}{|l|l|l|l|l|c|}
\hline No & \multicolumn{1}{|c|}{ Instansi } & \multicolumn{1}{|c|}{ Contact Person } & \multicolumn{1}{|c|}{ Tanggal Pemakaian } & \multicolumn{1}{c|}{ Kegiatan } & Jumlah Peserta \\
\hline 1 & UAJY & Bapak Ragil / 087963215821 & 10 May 2017 - 20 May 2017 & Lokakarya & 5 \\
\hline 2 & Amikom & Bapak Gili / 082122147852 & 13 May 2017 - 16 May 2017 & Retret & 4 \\
\hline 3 & safasfasf & asfasfasf / 3463463 & 12 May 2017 - 16 May 2017 & crncnc & 7 \\
\hline 4 & xcvvxcy & vxcrcx / 46363 & 13 May 2017 - 27 May 2017 & vncn & 7 \\
\hline \multicolumn{7}{|l|}{} & \multicolumn{1}{|c|}{ TOTAL } & $\mathbf{2 3}$ \\
\hline
\end{tabular}

JUNI

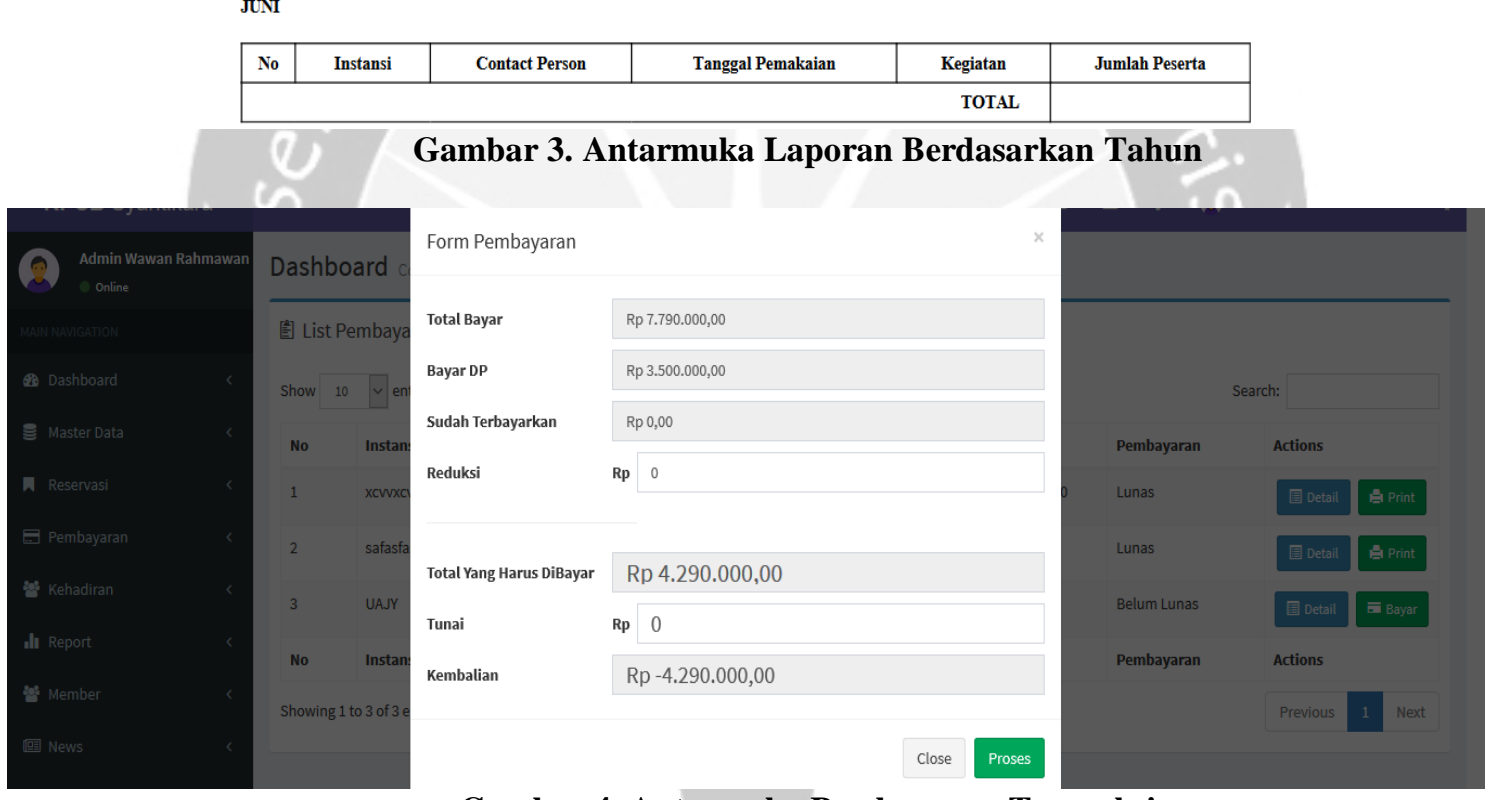

Gambar 4. Antarmuka Pembayaran Transaksi

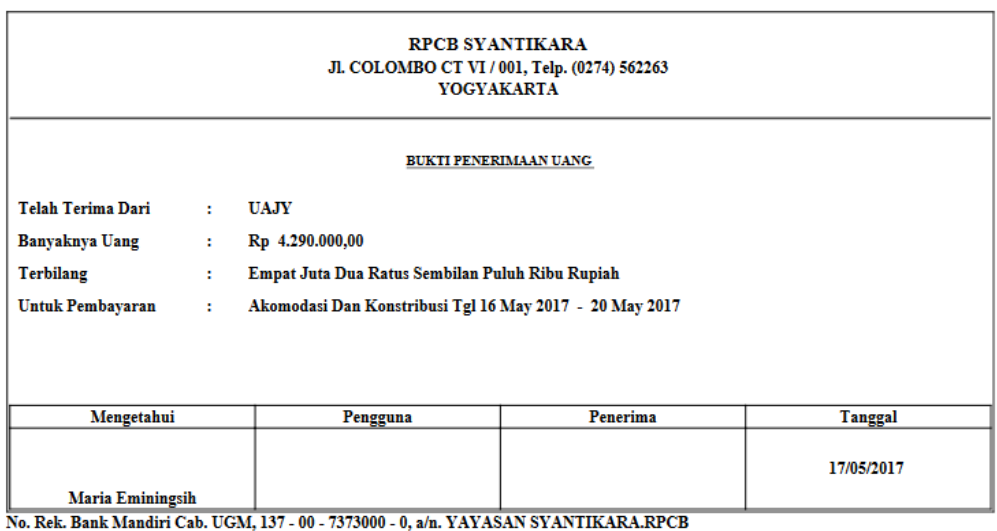

Gambar 5. Antarmuka Nota Transaksi Reservasi 
Antarmuka pada Gambar 6 digunakan oleh calon tamu untuk memesan ruangan dan kamar. Alur dari fungsi reservasi online ini: sistem memberikan form reservasi setelah mengisikan form maka sistem akan mengecek apakah jumlah tamu sesuai dengan batas maksimal tamu di RPCB Syantikara, dan mengecek apakah ada sisa kamar berdasarkan jumlah tamu yang diisikan. Jika mencukupi maka akan dibawa ke halaman generate kamar dan di halaman tersebut sistem mengisi kamar beserta ruangan sesuai dengan yang dibutuhkan. Setelah ruangan dan kamar sudah didapatkan, selanjutnya adalah pengisian data reservasi dan pembayarannya, yang dapat dilihat pada Gambar 7. Untuk lebih jelasnya flowchart dapat dilihat pada Gambar 8.

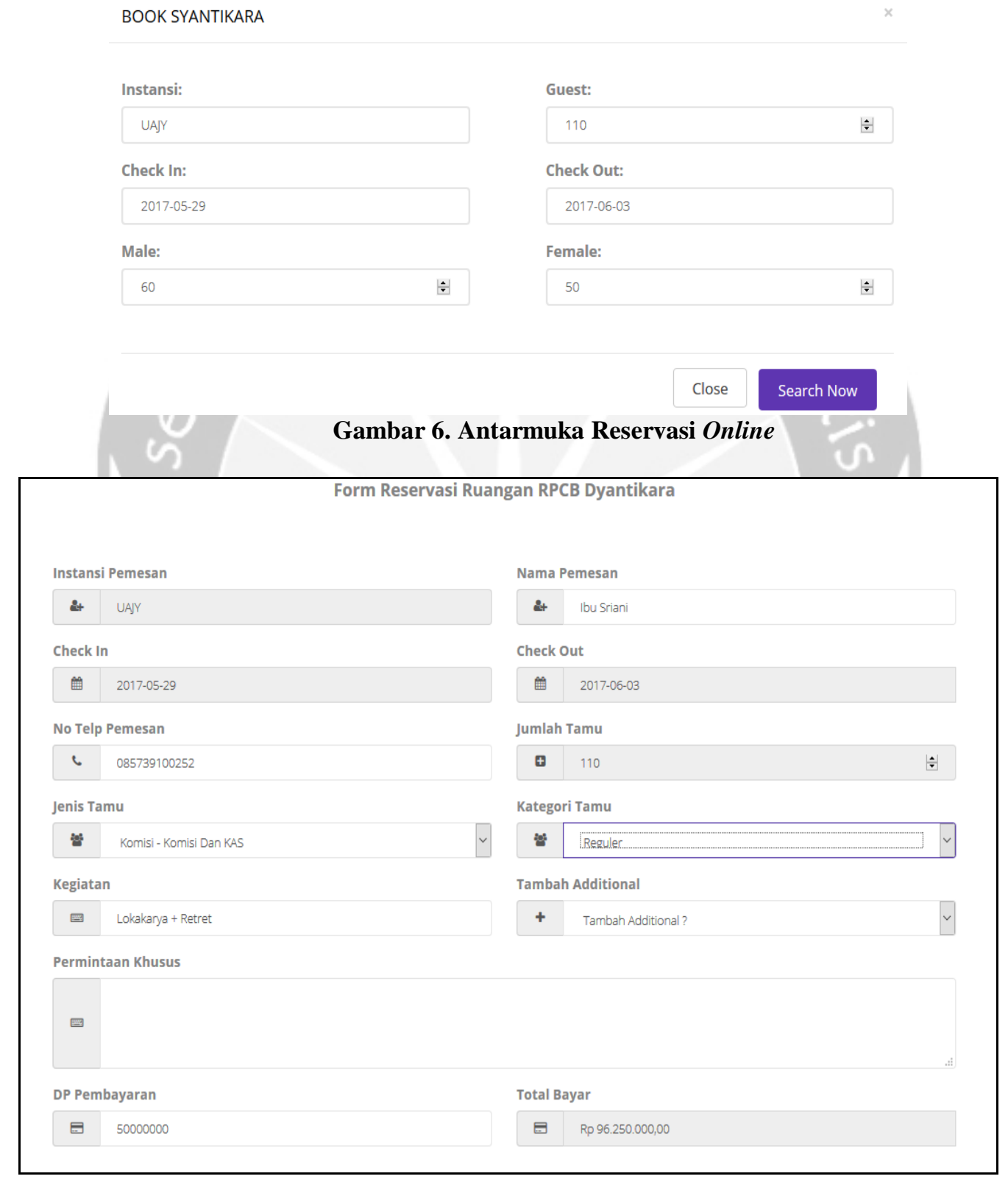

Gambar 7. Antarmuka Tambah Reservasi dan Pembayaran 


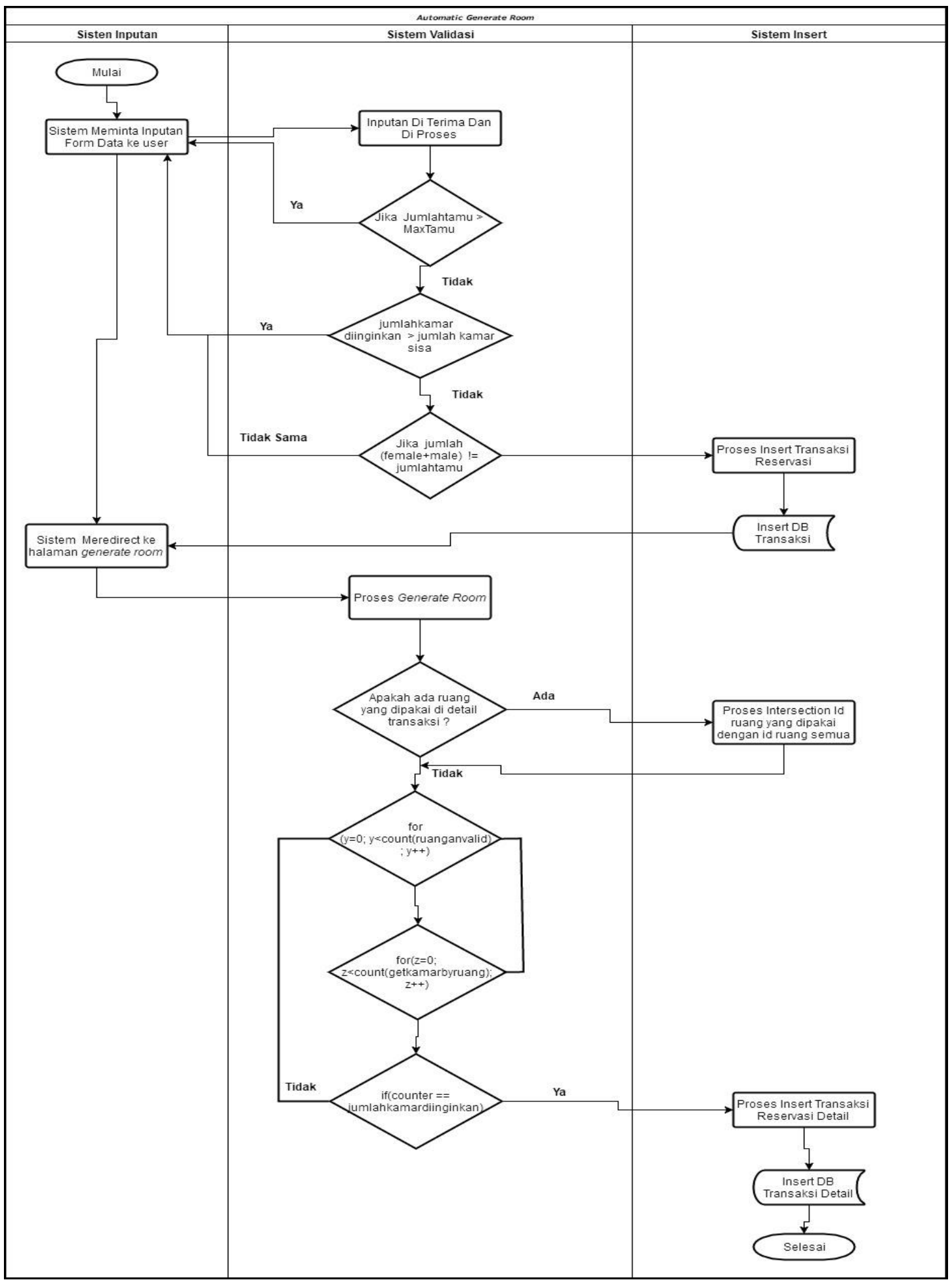

Gambar 8. Flowchart Reservasi Syantikara

\subsection{Pengujian Sistem}

Pengujian sistem informasi ini dilakukan dengan menggunakan metode blackbox testing untuk mengetahui kesesuaian aspek fungsionalitas sistem yang dijalankan. Teknis pengujian dilakukan dengan melaksanakan skenario pengujian oleh peneliti dan pengguna sistem. Berikut ini adalah hasil dari blackbox testing pada Tabel 1. 
Tabel 1. Hasil Blackbox Testing

\begin{tabular}{|c|c|c|c|c|}
\hline No & $\begin{array}{c}\text { Deskripsi } \\
\text { Pengujian }\end{array}$ & Skenario Pengujian & Hasil yang dicapai & Berhasil \\
\hline 1 & $\begin{array}{l}\text { Cek Ketersediaan } \\
\text { Kamar }\end{array}$ & $\begin{array}{l}\text { - Pilih menu 'Booking Now' } \\
\text {-Masukkan Intansi } \\
\text {-Masukkan tanggal check in } \\
\text {-Masukkan tanggal check out } \\
\text {-Masukkan jumlah tamu } \\
\text {-Masukkan jumlah tamu sesuai } \\
\text { jenis kelamin } \\
\text {-Pilih tombol 'Booking' }\end{array}$ & Sistem berhasil mengecek ketersediaan kamar & Berhasil \\
\hline 2 & $\begin{array}{l}\text { Tambah } \\
\text { Transaksi } \\
\text { Reservasi }\end{array}$ & $\begin{array}{l}\text { - Pilih menu 'Add Reservasi' } \\
\text {-Masukkan Intansi } \\
\text {-Masukkan nama pemesan } \\
\text {-Masukkan telepon } \\
\text {-Masukkan jumlah tamu } \\
\text {-Masukkan jenis tamu } \\
\text {-Masukkan jenis tarif } \\
\text {-Masukkan kegiatan } \\
\text {-Masukkan permintaan khusus } \\
\text {-Masukkan down payment } \\
\text {-Pilih tombol 'save' }\end{array}$ & $\begin{array}{l}\text { Aplikasi berhasil menambah data transaksi } \\
\text { reservasi }\end{array}$ & Berhasil \\
\hline 3 & $\begin{array}{l}\text { Pembatalan } \\
\text { Transaksi } \\
\text { Reservasi }\end{array}$ & $\begin{array}{l}\text {-Cari data transaksi reservasi yang } \\
\text { ingin dihapus datanya } \\
\text {-Tekan tombol 'Cancel' pada } \\
\text { baris data transaksi reservasi yang } \\
\text { dipilih 'Cancel } \\
\text {-Tekan tombol 'C } \\
\text { Reservation' pada dialog box }\end{array}$ & $\begin{array}{l}\text { Aplikasi berhasil menghapus data transaksi } \\
\text { reservasi dengan mengubah status menjadi } \\
\text { "cancel reservation" }\end{array}$ & Berhasil \\
\hline 4 & $\begin{array}{l}\text { Bayar Transaksi } \\
\text { Reservasi }\end{array}$ & $\begin{array}{l}\text {-Cari data pembayaran transaksi } \\
\text { reservasi yang ingin diproses } \\
\text { datanya } \\
\text {-Tekan tombol 'Bayar' pada baris } \\
\text { data pembayaran transaksi } \\
\text { reservasi yang dipilih } \\
\text {-Masukkan inputan untuk data } \\
\text { bayar transaksi reservasi } \\
\text {-Tekan tombol 'save' }\end{array}$ & $\begin{array}{l}\text { Aplikasi berhasil mengubah data pembayaran } \\
\text { transaksi reservasi }\end{array}$ & Berhasil \\
\hline 5 & Proses Kehadiran & $\begin{array}{l}\text {-Cari data transaksi reservasi yang } \\
\text { ingin diproses datanya } \\
\text {-Tekan tombol 'Check In' atau } \\
\text { 'Check Out' } \\
\text {-Tekan tombol 'Yes' Pada kotak } \\
\text { dialog konfirmasi }\end{array}$ & $\begin{array}{l}\text { Aplikasi berhasil mengubah status data } \\
\text { transaksi reservasi menjadi "check in" atau } \\
\text { "check out" }\end{array}$ & Berhasil \\
\hline 6 & $\begin{array}{l}\text { Pengujian Generate } \\
\text { PDF Laporan } \\
\text { Transaksi }\end{array}$ & $\begin{array}{l}\text { - Cari data laporan yang ingin } \\
\text { dilihat datanya } \\
\text { - Pilih tahun yang diinginkan } \\
\text { - Tekan tombol 'Go' } \\
\text { - Pilih Tombol 'Generate' untuk } \\
\text { mengenerate laporan menjadi } \\
\text { PDF }\end{array}$ & $\begin{array}{l}\text { Aplikasi berhasil mengubah data laporan } \\
\text { transaksi menjadi bentuk pdf }\end{array}$ & Berhasil \\
\hline
\end{tabular}

Dapat dilihat dari Tabel 1 di atas bahwa fungsionalitas utama pada sistem informasi manajemen dan reservasi untuk rumah pembinaan telah dilakukan dan berhasil dijalankan. Sistem menghasilkan keluaran yang sesuai dengan kebutuhan pengguna. Dari hasil implementasi kepada pengguna didapatkan bahwa sistem ini sudah dapat menjadi solusi bagi masalah yang dihadapi seperti proses pengelolaan data-data terkait reservasi, pencatatan reservasi, transaksi, sampai dengan pelaporannya yang dapat dipantau secara real time oleh petugas reservasi dan manajemen RPCB Syantikara.

\section{Kesimpulan}

Pada penelitian rancang bangun sistem informasi manajemen dan reservasi untuk rumah pembinaan menghasilkan beberapa kesimpulan sebagai berikut: (1) Sistem yang berhasil dibangun yaitu aplikasi website yang dapat digunakan oleh pihak internal rumah pembinaan, yaitu: kepala yayasan, pegawai, dan administrator. Selain itu juga dapat digunakan oleh pihak 
eksternal, yaitu tamu atau pelanggan. (2) Sistem Informasi Manajemen dan Reservasi rumah pembinaan berhasil diimplementasikan untuk menangani proses reservasi online dan dapat menyediakan infomasi yang dibutuhkan oleh manajemen sehingga dapat membantu manajemen dalam pengambilan keputusan.

\section{Referensi}

Akazue, M. I. (2016). Enhanced Hotel Management Information System for Multiple Reservation Booking. International Management Review, 12(1), 52-59.

Alhempi, R. R. \& Harianto, W. (2013). Pengaruh Pelatihan Dan Pembinaan Terhadap Pengembangan Usaha Kecil Pada Program Kemitraan Bina Lingkungan. Media Riset Bisnis \& Manajemen, XIII(1), 20-38.

Al-Mamary, Y. H., Shamsuddin, A., \& Aziati, N. (2014). The Role of Different Types of Information Systems in Business Organizations: A Review. International Journal of Research, 1(7), 333-339.

Aprillia, C. A., Astuti, E. S. \& Dewantara, R. Y. (2017). Analisis Sistem Informasi Reservasi Hotel (Studi Kasus Sistem Informasi Reservasi Dewarna Hotel Letjen Sutoyo Malang). Jurnal Administrasi Bisnis, 44(1), 111-117.

Aswati, S., Mulyani, N., Siagian, Y., \& Syah, A.Z. (2015). Peranan sistem infromasi dalam perguruan tinggi. Jurnal Teknologi dan Sistem Informasi, 1(2), 79-86.

Chandra, C.J. (2016). Perencanaan Strategis Sistem Informasi dan Teknologi Informasi Menggunakan Metode Ward dan Peppard. Seminar Nasional Teknologi Informasi dan Komunikasi 2016 (SENTIKA 2016), Universitas Atma Jaya Yogyakarta, Yogyakarta, 18-19 Maret 2016.

Delizo, G. A., \& Esguerra, M. A. (2013). Online Hotel Reservation and Management System for The College of International Tourism and Hospitality Management (CITHM). International Journal Of Computers \& Technology, 10(1), 1201-1229.

Ensour, H. S., \& Alinizi, T. M. (2014). The Impact of Management Information Systems (MIS) Technologies on The Quality of Services Provided at The University of Tabuk. International Journal of Network Security \& Its Applications, 6(2), 1.

Falgenti, K., \& Pahlevi, S. M. (2013). Evaluasi Kesuksesan Sistem Informasi ERP pada Usaha Kecil Menengah, Studi Kasus: Implementasi SAP B1 di PT. CP. Jurnal Manajemen Teknologi, 10, 161-183.

Jogiyanto, H. M. (2005). Analisis dan desain sistem informasi. Yogyakarta: Andi Offset.

Hasan, Y., Shamsuddin, A., \& Aziati, N. (2013). The impact of management information systems adoption in managerial decision making: A review. The International Scientific Journal of Management Information Systems, 8(4), 010-017.

Kim, T. G., Lee, J. H., \& Law, R. (2008). An empirical examination of the acceptance behaviour of hotel front office systems: An extended technology acceptance model. Tourism management, 29(3), 500-513.

Kurniawan, Y., \& Cassandra, C. (2014). Development of Church Information System (A Case Study Approach). International Journal of Software Engineering and Its Applications, 8(12), 199-208.

Manjunatha, B., Srinivas, T.R., Ramachandra, C.G., \& Neetha, K. (2016). Management Information System (MIS) in Hotel Industries to Improve Overall Efficiency. National Conference on Advances in Mechanical Engineering Science (NCAMES-2016).

Molchanova, V. S. (2014). The Use of Online Service Booking in Tourist Activity. European Journal of Social and Human Sciences, II(2), 75-80.

Munirat, Y., Mohammed, I., \& Kazeem, A. O. (2014). The Impact of Management Information System (MIS) on the Performance of Business Organization in Nigeria. International Journal of Humanities Social Sciences and Education (IJHSSE) Volume, 1, 76-86.

O'Brien, J., \& Marakas, G. (2011). Management Information Systems, $10^{\text {th }}$ edition. McGrawHill Education. 
Osama, S. (2011). Integrated Information System for reserving rooms in Hotels. International Journal of Advanced Computer Science and Applications (IJACSA), 2(10), 48-52. 